\title{
Reproductive biology of the freshwater drum Aplodinotus grunniens in Tabasco, Mexico
}

\section{Biología reproductiva del tambor de agua dulce Aplodinotus grunniens en Tabasco, México}

\author{
Raúl Enrique Hernández-Gómez ${ }^{1}$, Wilfrido Miguel Contreras-Sánchez ${ }^{2 *}$, Martha Alicia Perera-García ${ }^{3}$ \\ ${ }^{1}$ Laboratorio de Acuacultura, División Académica Multidisciplinaria de los Ríos, Universidad Juárez Autónoma de Tabasco, CP. \\ 86901, Tenosique-Estapilla Km 1.0. \\ ${ }^{2}$ Laboratorio de Acuicultura Tropical, División Académica de Ciencias Biológicas, Universidad Juárez Autónoma de Tabasco. \\ CP. 86039, Villahermosa-Cárdenas Km. 0.5, Entronque a Bosques de Saloya. \\ ${ }^{3}$ División Académica de Ciencias Agropecuarias, Villahermosa-Teapa Km. 25.0, Tabasco, México. \\ ${ }^{*}$ Corresponding author: contrerw@hotmail.com
}

Scientific article received: November 25, 2015 accepted: October 25, 2016

\begin{abstract}
Aplodinotus grunniens supports a sustained artisanal fishery in the Usumacinta River; however, there are few studies to understand the population dynamics of the species. Relevant aspects of the reproductive biology were documented over an annual cycle, using 593 specimens captured with seine nets. The results indicate that females had a median TL of $32.05 \mathrm{~cm}$, while males had $29.71 \mathrm{~cm}$. The estimated sex ratio was 1.2:1 (males: females). The length-weight relationship showed significant difference between sexes, observing an allometric-type growth represented by $\mathrm{TW}=0.0013(\mathrm{TL})^{3.5985}$ with $89.17 \%$ of the data variability explained by the model. Gonadosomatic index (GSI) in females was higher in September (4.29), with males displaying a higher GSI in October (1.02). The highest HSI increase in females was observed in October (1.0). The estimated relative fecundity was $138.74( \pm 74.30)$ oocytes/g of female weight. The macroscopic analysis of gonads indicates that the highest frequency of mature females occurs in June (75\%), while in males it takes place in March and June (35\%). The estimated $\mathrm{L}_{50}$ for females was $31.89 \mathrm{~cm}$ $(T L)$ and $28.78 \mathrm{~cm}(T L)$ for males. Though $A$. grunniens reproduces throughout the year, reproductive peaks coincide with the period when the river level decreases, and fishing increases considerably. Hence, preventive measures must be applied in regards to the size of the species at capture and the exploitation volumes of this resource.
\end{abstract}

Key words: Fishery biology, reproduction, Usumacinta river

RESUMEN. Aplodinotus grunniens soporta una pesquería artesanal sostenida en el río Usumacinta; sin embargo, existen pocos estudios que permitan entender su dinámica poblacional. Se documentaron aspectos relevantes de la biología reproductiva a lo largo de un ciclo anual, empleandose 593 especímenes capturados con redes de cerco. Los resultados indican que las hembras presentaron una mediana de $32.05 \mathrm{~cm}$ de $L T$ y los machos de $29.71 \mathrm{~cm}$. La proporción sexual estimada fue de 1.2:1 (machos: hembras). La relación longitud-peso presentó diferencias significativas entre sexos, observándose un crecimiento de tipo alométrico representado por $T W=0.0013(T L)^{3.5985}$, con un 89.17 $\%$ de la variabilidad de los datos explicada por el modelo. El índice gonadosomático (IGS) en hembras fue mayor en septiembre (4.29) y en machos en octubre (1.02), mientras que el mayor incremento de IHP en hembras se observó en octubre (1.0). La fecundidad relativa estimada fue de $138.74( \pm 74.30)$ ovocitos/g de peso de la hembra. El análisis macroscópico de gónadas indica que la mayor frecuencia de organismos maduros en hembras se presenta en junio (75 $\%$ ) y en machos en los meses de marzo y junio (35\%). La $L_{50}$ estimada para hembras fue de $31.89 \mathrm{~cm}$ (LT) y para los machos de $28.78 \mathrm{~cm}$ (LT). A. grunniens se reproduce la mayor parte del año, con picos reproductivos que coinciden con la disminución en los niveles del río y un considerable aumento de la pesca. Por lo tanto, se deben establecer medidas preventivas sobre su talla de captura y los volúmenes de explotación del recurso.

Palabras clave: Biología pesquera, Reproducción, río Usumacinta 


\section{INTRODUCTION}

The freshwater drum Aplodinotus grunniens belongs to a group of fish of the Sciaenidae family that includes organisms living in sea, salt and fresh water. This family comprises 70 genera with 270 species (Nelson 1994) that are distributed practically in all continents and constitute a major worldwide fishery resource. The freshwater drum is distributed throughout the Americas, in Canada from Quebec to Manitoba and Saskatchewan; in the US, east of the Rocky Mountains in San Lorenzo-Great Lakes, the Hudson Bay, the Gulf of the Mobile Bay in Alabama and Georgia, the Mississippi river, and in Central America, in the Gulf of Mexico, in the Usumacinta, Grijalva and San Pedro rivers and in southern Guatemala (Froese and Pauly 2011). The first studies of $A$. grunniens date back to 1950 and include information on its biology, feeding habits, spawning, and description of the egg, embryo and larva development (Edsall 1967). More recently, Rypel et al. (2006) studied its growth and age variation in rivers (lotic environment) where these fishes are significantly stronger and have longer life spans (>30 years), versus Alabama reservoirs (lentic environment). This same author conducted a study on sexual dimorphism in four Alabama rivers and found significant differences in the size of females and males (Rypel 2007). Other studies have been carried out in other species of the family on reproductive biology and population structure (Sirangelo and Ferreira 2004, Ramos-Miranda et al. 2009, Ferreira et al. 2011, Pombo et al. 2013, Militelli et al. 2013).

In Mexico, A. grunniens fishery takes place mainly in the states of Veracruz, Tamaulipas and Tabasco, with a reported production of almost $196.49 \mathrm{t}$ (CONAPESCA 2016). In the state of Tabasco fish biodiversity registry, this species is known under the common name of roncador de agua dulce (freshwater snorers or croakers) and has been catalogued as a vicarious species of the Usumacinta river basin (Espinoza-Pérez and Daza-Zepeda 2005). However, fishermen from the municipalities of Emiliano Zapata, Jonuta, Balancán and Tenosique (river zone) call it topuche or roncador. Investigations in Mexico on its biology, ecology, and fisheries are scarce; therefore, the objective of this study was to determine relevant aspects of the reproductive and population biology of Aplodinotus grunniens over an annual cycle.

\section{MATERIALS AND METHODS}

A total of 593 specimens of $A$. grunniens were collected between january and december 2013 from the commercial fishery of the Usumacinta river, Tenosique, Tabasco. The capture area covers the regions described by the inhabitants as the Usumacinta river Canyon Boca del Cerro (17 ${ }^{\circ} 25^{\prime}$ $33^{\prime \prime}$ North and $91^{\circ} 29^{\prime} 29^{\prime \prime}$ West ); the Isla (17 $28^{\prime} 25^{\prime \prime}$ North and $91^{\circ} 31^{\prime} 40^{\prime \prime}$ West), the Recreo (17 $29^{\prime} 05^{\prime \prime}$ North and $91^{\circ} 25^{\prime} 91^{\prime \prime}$ West); Chaculji (17 $29^{\circ} 57^{\prime \prime}$ North and $91^{\circ} 26^{\prime} 48^{\prime \prime}$ West), and the Copo ( $17^{\circ} 34^{\prime} 74^{\prime \prime}$ North and $91^{\circ} 29^{\prime} 89^{\prime \prime}$ West). The specimens were captured during the low water months using seine nets with a mesh size of $2 \mathrm{~cm}, 80$ $\mathrm{m}$ in length and $3.0 \mathrm{~m}$ in height; during the periods of increased water level, fish were captured using hook and line with crayfish Procambarus llamasi as bait. Fish were killed rapidly by a blow to the head.

From each of the organisms collected, the total length (TL) was recorded using a standard ictiometer of $100 \mathrm{~cm} \pm 1 \mathrm{~mm}$ precision; the total weight (TW), liver and gonad weight were determined using a Scout Pro ${ }^{T M}$ digital scale of 4000.00 $\mathrm{g}$ and $\pm 0.01 \mathrm{~g}$ precision. Both sex and sexual maturity were determined on the basis of gonad morphological characteristics and color in accordance with a maturation scale for partial spawning fish proposed by Nikolsky (1963) that comprises six stages: immature (I), quiescent (II), maturing (III), mature (IV), spawning (V), and spent (VI). Monthly male: female ratios were calculated for different maturity stages. The gonadosomatic index (GSI) was determined with the equation $\mathrm{GSI}=\mathrm{Wg} / \mathrm{Wt}^{*} 100$, where $\mathrm{Wg}=$ gonad weight, and $\mathrm{Wt}=$ specimen weight (Rossendllum et al. 1987). The hepatosomatic in$\operatorname{dex}(\mathrm{HSI})$ was determined with the equation $\mathrm{HSI}=$ $\mathrm{Wh} / \mathrm{Wt}^{*} 100$, where $\mathrm{Wh}=$ liver weight, and $\mathrm{Wt}=$ 
specimen weight (Rodríguez-Gutiérrez 1992). The physiological state or condition factor $(K)$ of each fish was obtained using the expression $\mathrm{K}=\mathrm{W} / \mathrm{L}^{b *} 100$ proposed by Ricker (1958).

The total length-weight relationship was calculated separately for both sexes by applying the mathematical relationship: $\mathrm{TW}=a \mathrm{TL}^{b}$, proposed by Ricker (1975), where TW is the total weight, a is the intercept, $T L$ the total length, and $b$ the slope (growth coefficient). The average size at sexual maturity, defined as the size and age at which $50 \%$ of fish are sexually mature $\left(L_{50}\right)$ and when all individuals are fit to actively participate in the reproductive process $\left(L_{100}\right)$, was determined on the basis of accumulated relative frequencies of male and female individuals, in maturity stages II and V (Luksenburg and Pedersen 2002), using the logistic equation method of King (2007): $\mathrm{P}=1 /\left(1+\exp ^{r(L-L m)}\right)$, where $r=$ slope of the curve, and $L_{m}=$ mean length of maximum gonad length to which $0.5(50 \%)$ of the ratio correspond.

Absolute fecundity was also calculated, understood as the number of mature or maturing oocytes found in the ovary. Estimates were conducted by taking three subsamples of $0.3 \mathrm{~g}$ ( \pm 0.001 ) in three sections of the gonad (anterior, middle and posterior), and the equation $\mathrm{Fa}=\mathrm{n}^{*} \mathrm{G} / \mathrm{g}$ was used; where $G=$ total weight of gonad, $g=$ weight of subsample, and $n=$ average number of oocytes (Bagenal 1978). Relative fecundity was estimated with the formula $\mathrm{Fr}=$ Total oocytes/weight of fish in $g$. In each of these techniques weight was obtained using a Scout Pro ${ }^{T M}$ digital scale of 4000.00 $\mathrm{g}$ and $\pm 0.01 \mathrm{~g}$ precision. Climate data such as water temperature $\left({ }^{\circ} \mathrm{C}\right)$, dissolved oxygen (DO), rainfall $(\mathrm{mm})$, and river water level (masl) were taken from the records of the National Water Commission.

The median weight and length values of males and females were compared using the MannWhitney (W) test since data did not meet the parametric criteria (Zar 1999). A multiple correlation analysis and ANCOVA were applied to the TL-TW regressions between sexes to identify possible differences between them (Sparre and Venema 1998). The sex ratio per month was compared using a Chi square test $\left(X^{2}\right)$ (Underwood 1997). Growth allometric equations were obtained with a logarithmic transformation (Sokal and Rohlf 1996). A Student's t-test $(\mathrm{t})$ was applied to the value of slope $b$ to determine the type of growth (Ibáñez and Fernández 2006). All the statistical analysis were performed considering an error margin $\alpha=0.05$.

\section{RESULTS}

Of the total number of specimens examined, 327 were males and 266 females. The males had a TL between 23.32 to $39.05 \mathrm{~cm}$ and a most frequent size of $29.00 \mathrm{~cm}$. In females, TL was between 24.90 to $46.10 \mathrm{~cm}$, with a most frequent size of $30.00 \mathrm{~cm}$ (Figure 1). Males showed significantly smaller weight and length with medians $=262.60 \mathrm{~g}$ and $29.71 \mathrm{~cm}$, than females with medians $=362.85 \mathrm{~g}$ and $32.05 \mathrm{~cm}$ (Mann-Whitney, $\mathrm{W}=23700.50$ and 23 430.00, $\mathrm{p}<0.001)$. The analysis of the length-weight relationship between females and males indicates that there are statistically significant differences between models (ANCOVA, $\left.F_{1,589}=144.46, p<0.001\right)$. The relationship for females was $\mathrm{TW}=0.0007(\mathrm{TL})^{3.7834}$ and for males $T W=0.0079(T L)^{3.0693}$. For both sexes the model obtained was TW $=0.0013(\mathrm{TL})^{3.5985}$, and the percent of data variability explained by the model $\left(R^{2}\right)$ was $90.78 \%$ for females, $81.22 \%$ for males and $89.17 \%$ for both sexes. The observed value of $b$ for the species (both sexes) is greater than three, an indication that the species presents an allometric-type growth $\left(\mathrm{t}_{2}=4.48, \mathrm{p}<0.05\right)$ (Figure 2). Males represented $55.15 \%(n=327)$ of analyzed organisms, while females represented $44.85 \%(n=266)$, leading to a male: female ratio of $1.2: 1$. Males showed a higher ratio in the months of june $(71 \%)$ and october $(72 \%)$, while females had maximum values slightly over $50 \%$ in april (54 $\%)$, august $(55 \%)$, and december $(52 \%)$. The total male and female ratios were statistically different in january. The general ratio between sexes showed statistically significant differences $\left(X^{2}{ }_{11}=\right.$ $21.40, p=0.02$ ) (Figure 3 ). In july and september only females were captured (1 and 2, respec- 


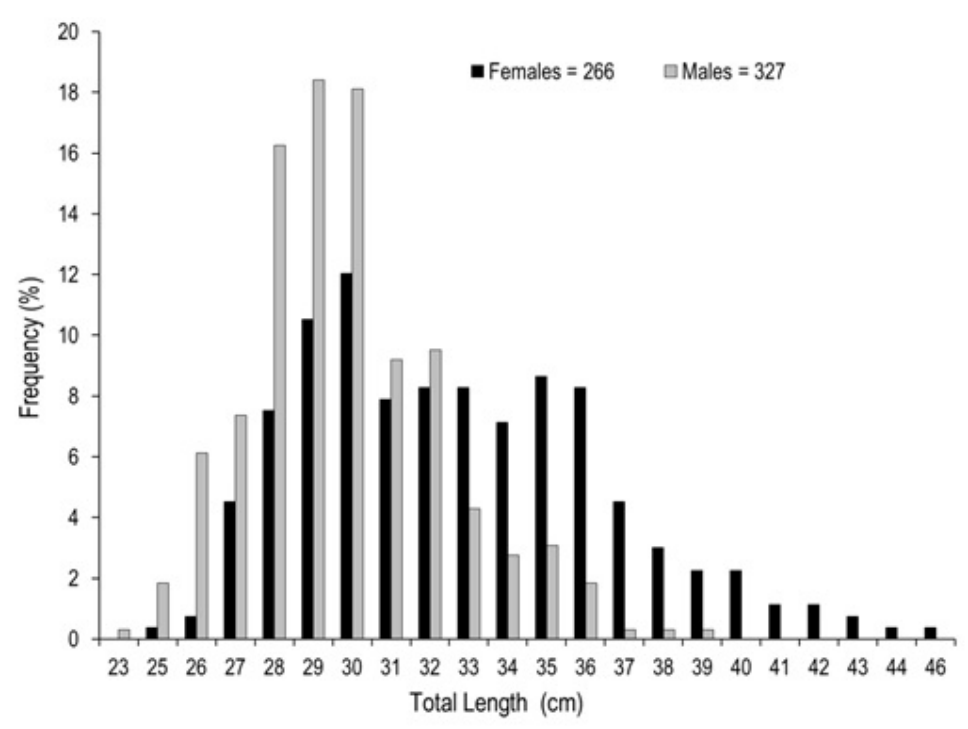

Figure 1. Total length frequency distribution of $A$. grunniens collected in the Usumacinta River, Tabasco, Mexico.

tively) due to the high river level. For this reason, the values of GSI, HSI, and $\mathrm{K}$ in males were impossible to determine for these months. The maximum GSI values in females occurred during june (3.78), august (3.95), september (4.29), and october (3.48). In the remaining months this value was below 2.5. In males, the maximum value appeared in october (1.02), and it was below 1.0 in the other months (Figure 4). The hepatosomatic index (HSI) values for females showed their maximum values in august (0.91) and october (1.00), while the minimum was recorded in July (0.56). In the case of males, the maximum value was recorded in december (0.82) and the minimum in April (0.46) (Figure 4). The estimated $K$ values had little variability throughout the year for both sexes, showing a slight increase for females in august, september, and october. The $\mathrm{K}$ maximum values recorded for both sexes occurred in august (females 1.65 and males 1.41). The minimum values observed were 1.35 for females (july) and 1.24 for males (february and april) (Figure 5).

The average absolute fecundity ( \pm SD) estimated for the species $(n=50)$ was 68055.17 ( \pm 49120.62 ) oocytes, within a range of 9632 to 223 800 . The obtained relative fecundity was $138.74( \pm$
74.30) oocytes/g of female weight, within a range of 33.43 to 323.87 oocytes/g of weight.

In terms of maturity stages, we found that the most frequently recorded stages in females were quiescent (II) and spawning (V). Females in maturing stage (III) showed the highest value in september, october, and november. Females in mature stage (IV) were found in february, april, june, october, and november. With the exception of september, there were females in spawning stage (V) throughout the reproductive cycle, with march, april, june, and august standing out for their higher frequency. Spent females (VI) were more frequently recorded in april, june, july, and october. Two females analyzed in July showed the higher frequency (Table 1, Figure 6). In regards to males, the quiescent (II) and maturing (III) stages were the most frequent during the annual cycle. The mature stage (IV) displayed the maximum values in february and october. The male specimens in spawning stage $(V)$ were recorded throughout the annual cycle, but with a higher frequency in march and june. Spent males (VI) showed their maximum frequency in june and august, respectively (Table 1, Figure 6).

The average length at first maturity in females was $31.89 \mathrm{~cm}$, the length at which they are 
Hernández-Gómez et al.
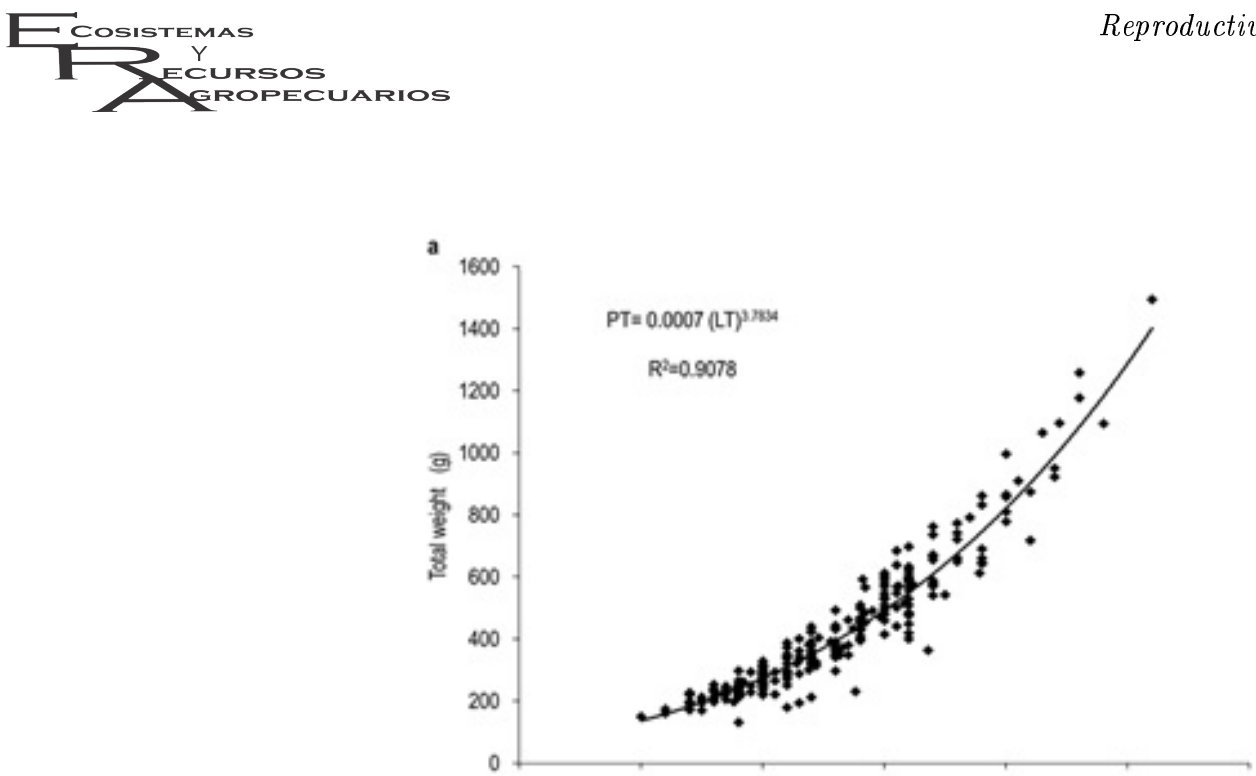

b
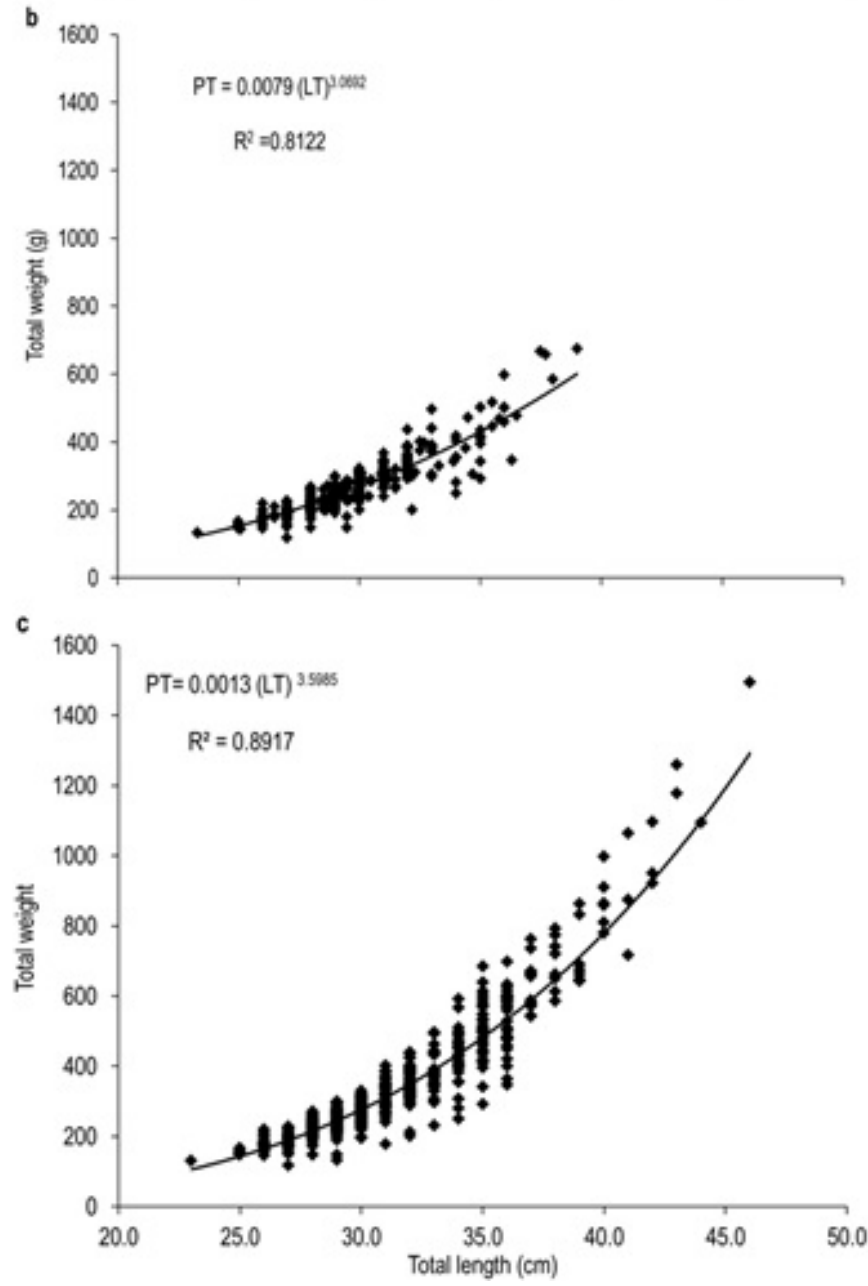

Figure 2. Length-weight relationship of $A$. grunniens from the Usumacinta River, Tabasco, Mexico, (a) Females, (b) Males, and (c) both sexes $(\mathrm{N}=593)$.

fit for spawning $\left(L_{100}\right)$ was $45.85 \mathrm{~cm}$ of $\mathrm{TL}$. In 


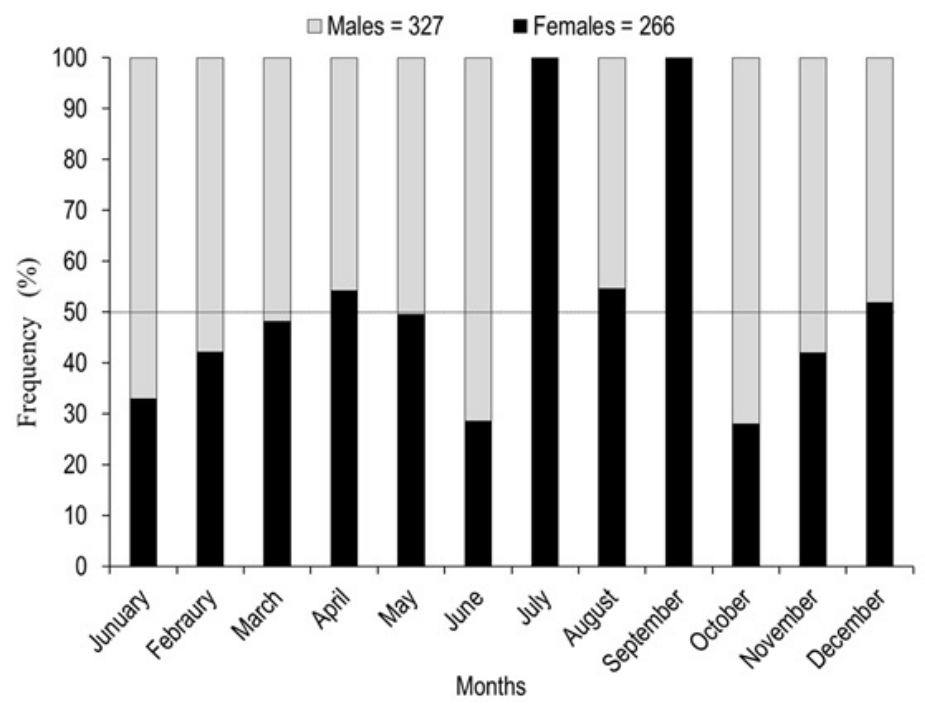

Figure 3. Monthly sex ratios of $A$. grunniens from the Usumacinta River, Tabasco, Mexico.

Table 1. Macroscopic description of gonad maturity stages of $A$. grunniens from the Usumacinta River, Tabasco, Mexico (based on Nikolsky, 1963).

\begin{tabular}{|c|c|}
\hline Stage & Description \\
\hline Immature (I) & $\begin{array}{l}\text { Translucent ovaries, of reduced size, next to the dorsal wall under the swim bladder. They occupy approximately } \\
1 / 2 \text { of the coelomic cavity, with an extremely thin and dilated vascularized line. Translucent, narrow and threadlike } \\
\text { testes, with a pink color. Their location is similar to that of ovaries. }\end{array}$ \\
\hline Quiescent (II) & $\begin{array}{l}\text { Vascularized and semitransparent ovaries, occupying } 1 / 2 \text { to } 2 / 3 \text { of the coelomic cavity. They are slightly narrower } \\
\text { in the red to burgundy anterior part, with an apparently yellowish cylindrical posterior part. Oocytes are not } \\
\text { distinguishable macroscopically. Testes in the shape of white bands with pinkish peripheries. They are wider in } \\
\text { their posterior part versus the anterior. }\end{array}$ \\
\hline Maturing (III) & $\begin{array}{l}\text { Slightly bigger ovaries, occupying } 2 / 3 \text { of the coelomic cavity length. They are uniform in width, with visible } \\
\text { oocytes that resemble whitish to yellowish granules. Testes notably wider and with a smooth consistency, white, } \\
\text { with a light pink in their posterior part. }\end{array}$ \\
\hline Mature (IV) & $\begin{array}{l}\text { Ovaries with a big diameter, occupying } 2 / 3 \text { of the coelomic cavity. They are vascularized, with bigger oocytes, the } \\
\text { contour of which is starting to be defined. Lobed, developed testes, wider in the anterior region. Their smooth } \\
\text { structure is white and seminal liquid is expelled with a simple pressure. }\end{array}$ \\
\hline Spawr & $\begin{array}{l}\text { Ovaries with a homogeneous development, mainly in regards to width, completely occupying the coelomic cavity } \\
\text { and show slight vascularization. Oocytes are spherical, orange to yellowish, and visible at naked eyed. Increased } \\
\text { testicular size, both anteriorly and posteriorly, the latter being wider and lobed. With a milky consistency when } \\
\text { exposed to a simple pressure, expelling abundant seminal liquid. }\end{array}$ \\
\hline Spent (VI) & $\begin{array}{l}\text { Flaccid ovaries, with distended membranes and hemorrhagic appearance in their anterior part. They occupy } 1 / 3 \\
\text { of the coelomic cavity. Granule-like oocytes can be observed. Testes occupy the coelomic cavity like female } \\
\text { ovaries do. Their anterior part is thinner and more flaccid than their posterior part. The posterior part is lobed, } \\
\text { white, with a soft consistency. }\end{array}$ \\
\hline
\end{tabular}

males, the average length at first maturity was $28.78 \mathrm{~cm}$ and all males are fit for spawning from $41.90 \mathrm{~cm}$ of TL (Figure 7). Throughout the annual cycle studied, a mean water temperature of $26( \pm$ 1.44) ${ }^{\circ} \mathrm{C}$ was recorded in the Usumacinta river, with a minimum of $24{ }^{\circ} \mathrm{C}$ in december and a maximum of $29{ }^{\circ} \mathrm{C}$ in May. The DO recorded an average of $8.25( \pm 0.62) \mathrm{mg} \mathrm{L}^{-1}$, with a minimum of 7 $\mathrm{mg} \mathrm{L}^{-1}$ during june and a maximum of $9 \mathrm{mg} \mathrm{L}^{-1}$ during april, may, july, and august. $\mathrm{pH}$ averaged $7.83( \pm 0.38)$, with a minimum of 7.00 in april and september and a maximum of 8.00 for the remaining months of the annual cycle. Rainfall averaged 8.70 $( \pm 5.33) \mathrm{mm}$, with a minimum of $4 \mathrm{~mm}$ in april and a maximum of $19 \mathrm{~mm}$ in November. The river 

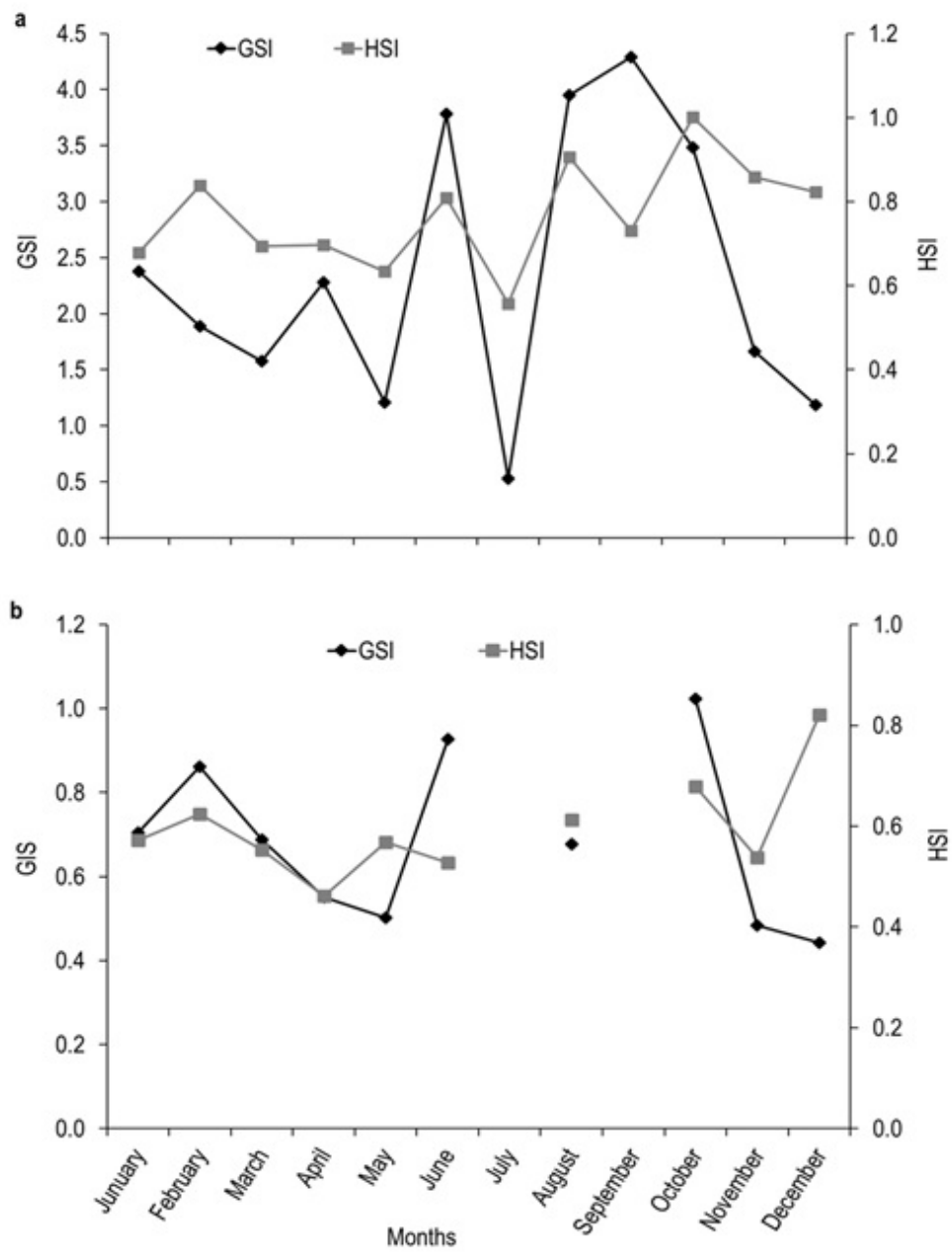

Figure 4. Gonadosomatic index (GSI) and hepatosomatic index (HSI) in (a) females and (b) males from the Usumacinta River, Tabasco, Mexico. Empty spaces in the lines indicate lack of organisms during sampling $(N=593)$.

level was $15.18( \pm 2.78)$ masl, with a minimum of 11.70 in april and may and a maximum of 18.90 in september and november, respectively.

\section{DISCUSSION}

Despite the small mesh size used $(2 \mathrm{~cm})$ for seining, during the period of study of $A$. grunniens, a size distribution between 20.00 and $46.00 \mathrm{~cm}$ (TL) was recorded. These values are similar to the range recorded by Chávez et al. (1989) at the San Pedro river in Tabasco, Mexico, which was from 19.00 to $47.10 \mathrm{~cm}$. Although there are no studies reporting freshwater drum juveniles or larvae in the area, we speculate that early stages of the life cycle may occur in the lower portion of the river, since floating eggs and larvae are transported downstream by currents. Furthermore, Rypel et al. (2006) reported that size distributions of freshwater drums captured in Alabama habitats using electrofishing and gill nets, were skewed toward juveniles in lentic reservoirs and adults in rivers; proposing that freshwater drum make movements of some scale across aquatic landscapes during their lives. Marcano et al. 


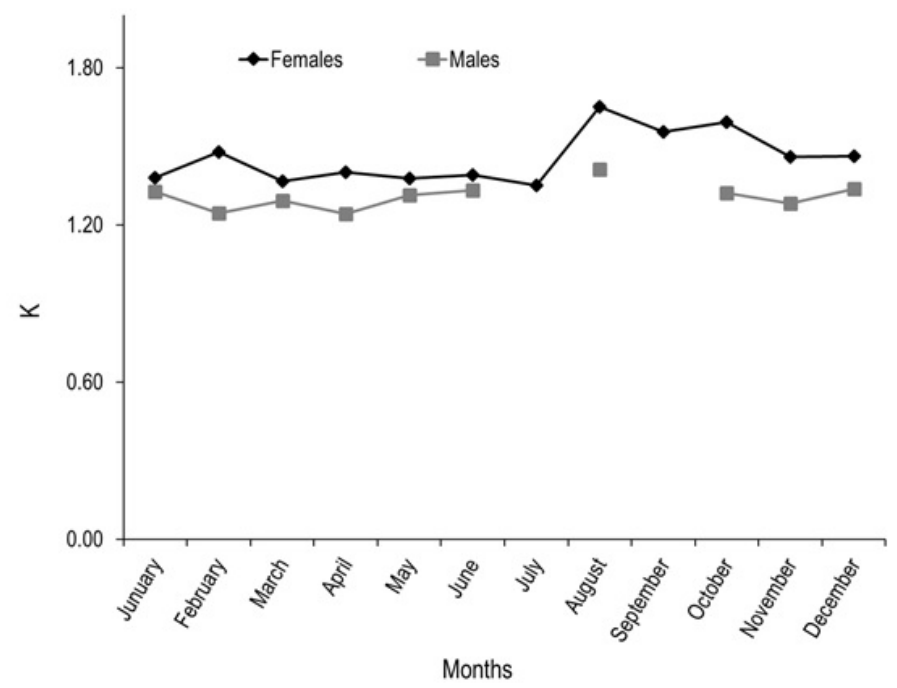

Figure 5. Condition factor $(\mathrm{K})$ in females and males of $A$. grunniens from the Usumacinta River, Tabasco, Mexico. Empty spaces in the lines indicate lack of organisms during sampling $(\mathrm{N}=593)$.

(2002) suggest that size structure depends on the environment they live in, mainly in terms of food availability, population density and ecological factors. Therefore, the recording of large sizes in our sampling grounds may be conditioned by a migratory behavior of the species, as is the case with other fish species. Reports of the early life history of this species indicate that movements between habitats may also be associated with changes in diet (Swedberg and Walburg 1970). This behavior stands out as an adaptation to exploit the seasonal productivity in different areas, at different times of the year, and among specific feeding, habitat and spawning areas (Saborido 2005). Our data suggest that freshwater drum use this portion of the Usumacinta river as spawning grounds, using other areas of the system as nursery grounds. Unfortunately, there have been no attempts at documenting this behavior.

In this study, A. grunniens females were significantly bigger than males, a condition similar to that reported by Rypel (2007) in the lakes and rivers of Alabama, US. However, it differs from the data recorded by Edsall (1967) in Lake Erie, where the specimens showed similar sizes for both sexes. The difference observed in the size of females may be attributed to intrinsic (genetic) factors of the species, type of habitat, and time of year (Gómez and Guzmán 2005). Nevertheless, Saborido (2005) considers that the main factor in controlling growth, survival, and reproduction is the energy acquired by fish through feeding.

The observed length-weight relationship showed an allometric-type growth similar to that reported by Chávez et al. (1989), for organisms captured in the San Pedro river, Balancán, Tabasco, Mexico. In relation to the allometry observed in A. grunniens, Jacquemin and Pyron (2013) pointed out that body size contributes more importantly to morphological variation than sex variations or river location. At the same time, they established that the interaction between body size, maturity, and river location indicates that an individual's morphology is not necessarily a direct relation between the fish and their environment, but rather it is multifaceted and results from the combination of allometry, sex and river location (local habitat). They also mention that the most noticeable change in size occurs during ontogeny, the time when embryos, larvae and/or juveniles grow, and that many allometry examples are ontogenetic in type. This allomet- 

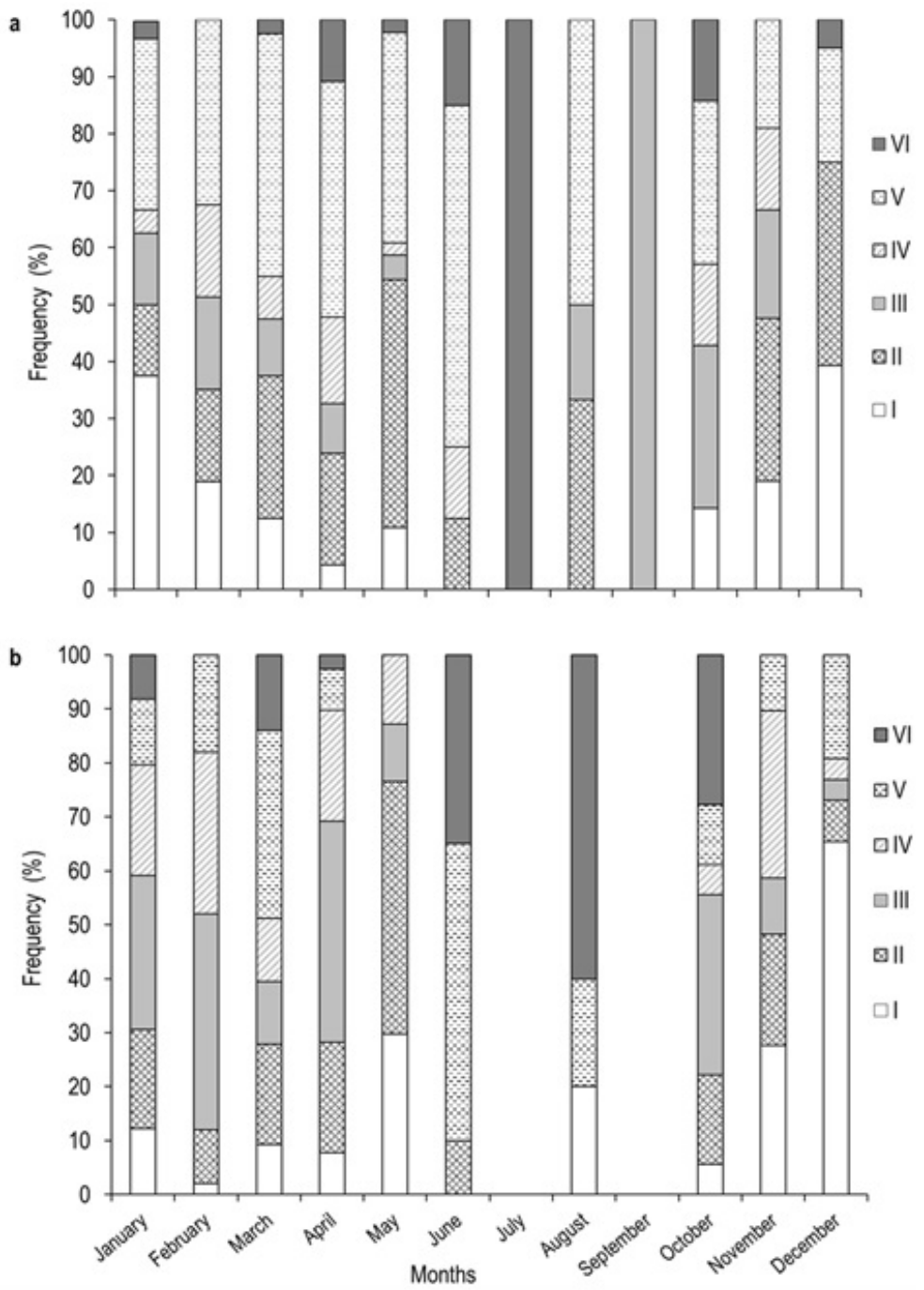

Figure 6. Maturity stage distribution frequency in (a) females and (b) males of $A$. grunniens from the Usumacinta River, Tabasco, Mexico. Empty spaces indicate lack of organisms during sampling.

ric condition is similar to that of other Sciaenidae species, such as the Micropogonias furnieri in the Gulf of Paria, State of Sucre, Venezuela, and the Cienega Grande de Santa Marta in the Caribbean region of Colombia (Gómez and Guzmán 2005, Cancio et al. 2006). The data of this study differed from those recorded for other marine origin species of the same family with isometric growth, such as Stellifer lanceolatus, from the southern region of the Gulf of Mexico, and Pogonias cromis, in northeast Florida
(Ramos-Miranda et al. 2009).

The sex ratio obtained in this study is close to an equilibrium between males and females in the population ( $55 \%$ males: $45 \%$ females), so apparently this species conforms to fisher's theory on equal sex ratios. In other studies with $A$. grunniens and despite using different sampling methods, several authors have reported proportions close to the one found in this study, indicating slight biases toward one or the other gender. Jacquemin 

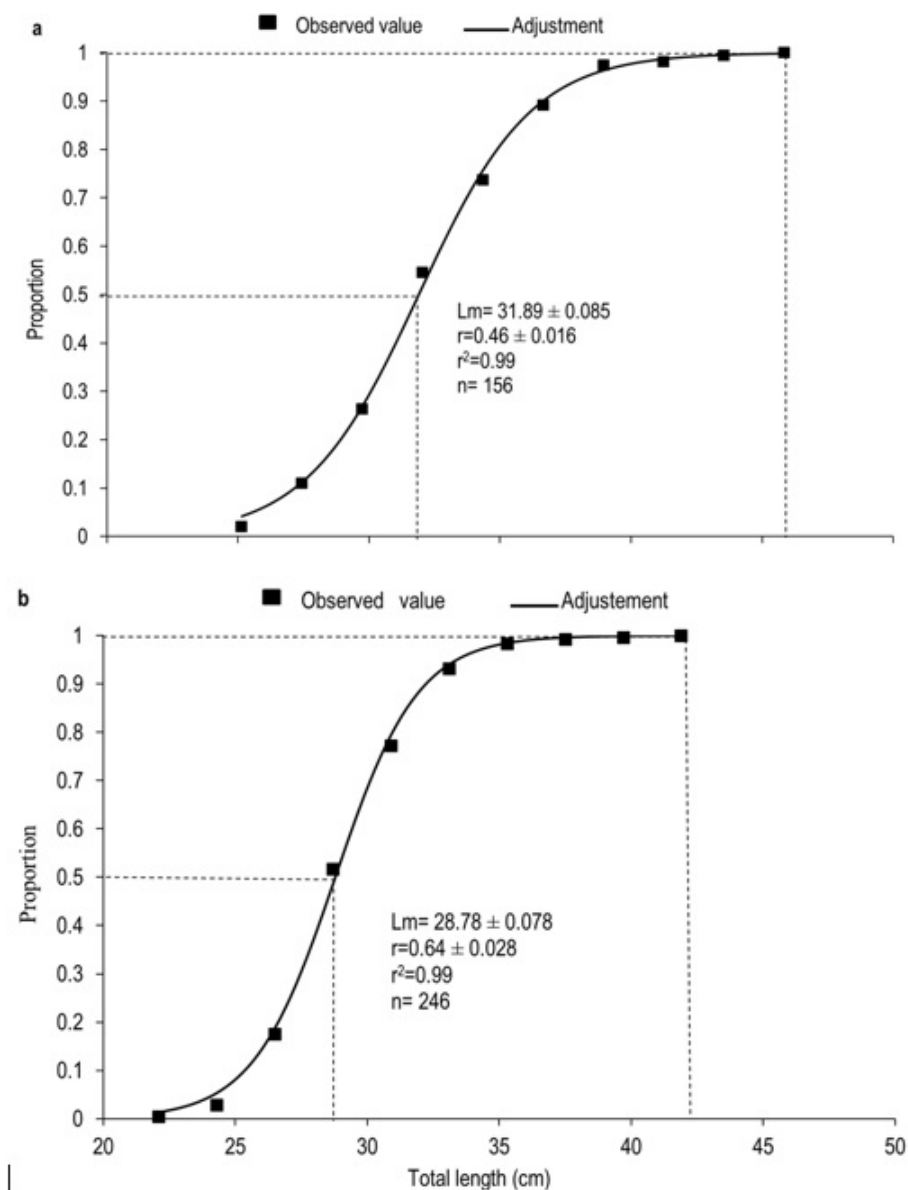

Figure 7. Mean maturity length ( $L 50)$ and maximum maturing length (L100) of females (a) and males (b) (stage II to $\mathrm{VI}$ ) of A. grunniens from the Usumacinta River, Tabasco, Mexico.

and Pyron (2013) reported a ratio of 1.01:1.00 in specimens captured in the Wabash river, being similar to the ratio recorded by Edsall (1967) for the same species in Lake Erie. In turn, this ratio also resembles the one reported by Grua et al. (2009) for marine origin species of the same group (Sciaena umbra and Cynoscion albus) in the Gulf of Montijo, Panama, and in the Balearic Islands, Spain, respectively, while Potts et al. (2010) reported 1.00:1.40 for Argyrosomus coronus in the mouth of the Kunene Estuary and Baia Farte, Angola. On the other hand, Chávez et al. (1989) in the San Pedro river and Rypel (2007) in different habitats in Alabama found sex ratios favoring females (0.65:1.00 and 0.71:1.00, respectively).
The GSI is used in gonadal development studies as an indicator that helps describe the reproductive cycle. In this work, four reproductive peaks were noted in june, august, september, and october for females, while there were only three peaks for males in february, june, and october. The GSI consistency for both sexes in some months establishes a synchronization of reproduction. These data indicate that $A$. grunniens is a sequential spawning species that reproduces most of the year. Similar results were reported for southern US, in the Ohio river, where the spawning of this species spans over five months, from april to september. However, the spawning season in the western region of Lake Erie was reported for june, july, and november, 
and for may and june in Texas, with temperatures ranging between 18 to $26{ }^{\circ} \mathrm{C}$ (Wallus and Simon 2006, Chad et al. 2007). In the case of Mexico, gonads in an advanced stage of maturity were observed most of the year in the San Pedro river, Tabasco (Chávez et al. 1989). Moreover, in the current study $A$. grunniens showed a reproductive behavior that is similar to that of other Sciaenidae species, such as Larimichthys polyactis (yellow sea bass), Sciaena umbra (banded sea bream), and Plagioscion squamosisimus (sea bass), in Korea, the Balearic Coast, Spain, and the Ucayali Coast, Peru, respectively (Grau et al. 2009, Lim et al. 2010).

The HSI in females is considered as an indicator directly linked to the reproductive cycle and decreases right before spawning (Rodríguez-Gutierrez 1992). This relationship is based on the fact that the liver produces vitellogenin during vitellogenesis, a protein that is taken by oocytes in development as reservoirs of nutrients and energy for embryos and larvae. Taking into account this physiological activity, the female HSI in this study shows a decrease in march, april, may, and july, while in males it is reduced in march, april, june, and november. The trend is not clear since this index decreases like the GSI and later diverges in the other sampling months. Nevertheless, to ensure that reproduction is established in this way, it is necessary to have a greater number of specimens during july and september. Moreover, Grau et al. (2009) pointed out that there is a similar behavior in Sciaena umbra, where both the HSI and GSI decrease from may to august, and then diverge from september to october.

In this study, the $\mathrm{K}$ factor indicates that, during the reproductive cycle, $A$. grunniens showed a good condition, was feeding and using energy constantly for the maturation of the ova mainly from february to june. However, the values of $\mathrm{K}$ increased from august to december, the period with the highest rainfall in the study area. Hence, this increase may be related to the accumulation of energy in the form of fat, an adaptive physiological strategy used for generating an energy reservoir as observed for the Menticirrhus littoralis species (Sirangelo and
Ferreira 2004). Rypel et al. (2006), noted that the lipids and physical condition of $A$. grunniens are significantly related with the type of habitat and vary with the age of the fish. However, this increase in the value of $\mathrm{K}$ may be conditioned by food availability during the period of increased river level which, in turn, reduces the possibility of feeding for species like this that have benthonic habits and mainly consume clams, bottom crustaceans and worms, and occasionally fish (Jacquemin and Pyron 2013). Nevertheless, the observed variation ok $\mathrm{K}$ may be interpreted as the period of sexual conditioning of the population prior to reproduction and spawning. This factor is associated with the biological and ecological phenomena of recruitment, growth, maturity and spawning like in the case of Cynoscion arenarius, in the southern Gulf of Mexico, and Euthynnus lineatus, in the coastline of Oaxaca, Mexico (Ramos-Cruz 2009).

In regards to fecundity, Rypel (2007) mentions that $A$. grunniens is a highly fecund species ( $>1$ million eggs). However, in this study, female fecundity $(n=50)$ was significantly lower than this value, as well as for other reported fecundity data for the species, like the findings of Chávez et al. (1989) in the San Pedro river, Balancan, Mexico, and Daiber (1953), in Lake Erie, as well as the case reported by Chad et al. (2007) for a $3.5 \mathrm{~kg}$ female in Texas with 600000.00 eggs. For the Lewis and Clark Lake, US, 6 to 9-year-old females $(n=17)$, with a TL between 30.70 and $38.60 \mathrm{~cm}$ and a weight of 295.00 to $670.00 \mathrm{~g}$, were reported to have a range of 34000.00 to 65500.00 eggs. However, the average fecundity of 68055.00 eggs recorded in the current study is within the ranges mentioned above. This variation may be due to differences in maximum sizes of females present in the Usumacinta system. In this sense, Wallus and Simon (2006) established that the reproductive potential variation of the species may be modified by feeding, reproductive status, age, length and weight, as well as temperature.

The highest proportion of sexual maturity (stage $V$ ) found in this study for the period from january to june and from october to december, with 
an average temperature of $27^{\circ} \mathrm{C}$, is in line with the study carried out in the San Pedro river, Balancán, Tabasco, Mexico, as well as for the data recorded from the beginning of May to july in Texoma Lake, from may to july in the Mississippi river, and in june for Lake Winnebago and Lake Erie, and Canada, respectively. It differs from those of mature specimens captured in the Tennessee river, in september (Chávez et al. 1989, Wallus and Simon 2006).

The mean lengths at first maturity $\left(L_{50}\right)$ of $A$. grunniens in this study were higher than those determined for females $(28.6 \mathrm{~cm})$ and males $(25.1 \mathrm{~cm})$ of the San Pedro river, Balancán, Tabasco, Mexico, as well as those of another species of the family in the Balearic Islands, Spain (Chávez et al. 1989, Gil et al. 2013). However, they are similar to the values obtained in marine Sciaenids, such as the catfish (Plagioscion squamosissimus) in Ucayali, Peru, Micropogonias furnieri in the Gulf of Paria, Sucre, Venezuela, Macrodon ancylodon in the Estuary of Caete, northern Brazil; and from those reported for Plagioscion magdalenae in the Bay of Marajo, estuary of the Amazon river (Gómez and Guzmán 2005, Barbosa et al. 2010). This shows that $L_{50}$ may be the consequence of genetic variability and size among the species of Sciaenidae. The data generated by $L_{50}$ are relevant since they are used as a management strategy for fishing management plans, for the species to be captured at sizes greater than those of first maturity (Perera-García et al. 2008).

\section{CONCLUSIONS}

Aplodinotus grunniens can reproduce practically during the entire year. The species presents a marked sexual dimorphism, with females being larger than males, and differences in the mean maturity length and growth indicators. This research provides baselines to propose a strategy for fisheries management in the region, with the intention of incorporating strategies for the conservation of the species.

\section{ACKNOWLEDGMENTS}

This paper resulted from joint efforts between the Universidad Juárez Autónoma de Tabasco, the Programa de Mejoramiento del Profesorado (PROMEP) and Fondos Mixtos CONACYTGovernment of Tabasco.

\section{LITERATURE CITED}

Bagenal TB (1978) Method for assessment of fish production in fresh waters. Blackwell Scientific Publications, London. 365p.

Barbosa SN, Da Rocha RM, Fredóu FL (2010) Reproductive biology of Plagioscion magdalenae (Teleostei: Sciaenidae) (Steindachner, 1878) in the bay of Marajo, Amazon Estuary, Brazil. Neotropical Ichthyology 8: $333-340$.

Cancio ME, Narváez BJC, Blanco RJ (2006) Dinámica poblacional del coroncoro Micropogonias furnieri (pisces: sciaenidae) en la ciénaga grande de Santa Marta, Caribe Colombiano. Boletín de Investigaciones Marinas y Costeras 35: 37-58.

Chad T, Bonner TH, Bobby G (2007) Freshwater fish of Texas: a field guide: freshwater drum Aplodinotus grunniens. Texas freshwater fishes. Texas State University-San Marcos. 5p.

Chávez LMO, Mattheeuws AE, Pérez MHV (1989) Biología de los peces del río San Pedro en vista de determinar su potencial para la piscicultura. 1ra. Edición INIREB, Xalapa, Veracruz, México. 222p

CONAPESCA (2016) Base de datos producción anuario 2014. Comisión Nacional de Acuicultura y Pesca. http:www.conapesca.sagarpa.gob.mx/wb/cona/cona_anuario_estadistico_de_pesca. Date consulted: August 12, 2016. 
Daiber FC (1953) Notes on the spawning population of the freshwater drum (Aplodinotus grunniens Rafinesque) in Western Lake Erie. American Midland Naturalist 50:159-171.

Edsall TA (1967) Biology of the freshwater drum in Western Lake Erie. The Ohio Journal of Science 67: 321-340.

Espinosa-Pérez H, Daza-Zepeda A (2005) Peces. En: Bueno J, Álvarez F, Santiago S (ed). Biodiversidad del estado de Tabasco. Instituto de Biología, Universidad Nacional Autónoma de México, Comisión Nacional de Biodiversidad, México. DF. pp: 225-240.

Ferreira CH, Abilhoa V, Oliveira FM, Maia CMF, Hostim-Silva M (2011) Estrutura populacional e biologia reprodutiva de Menticirrhus americanus (Linnaeus, 1758) (Teleostei, Sciaenidae) na baía de UbatubaEnseada, Santa Catarina, Brasil. Biotemas 24: 47-59.

Froese R, Pauly D (2011) FishBase. World Wide Web electronic publication. URL: www.fishbase.org. Date consulted: August 7, 2015.

Gil MM, Grau AG, Basilone RF, Palmer M (2013) Reproductive strategy and fecundity of meagre Argyrosomus regius Asso, 1801 (Pisces: Sciaenidae): implications for restocking programs. Scientia Marina 77: 105118.

Gómez G, Guzmán R (2005) Aspectos de la dinámica reproductiva y poblacional del rocador, Microgonias furnieri, en el golfo de Paria, Estado de Sucre, Venezuela. Zootecnia Tropical 23: 69-90.

Grau A, Linde M, Grau AM (2009) Reproductive biology of the vulnerable species Sciaena umbra Linnaeus, 1758 (Pisces: Sciaenidae). Scientia Marina 73: 67-81.

Ibáñez AAL, Fernández BLA (2006) Manual técnico de crecimiento relativo y análisis morfométrico. Universidad Autónoma Metropolitana, México, DF. 145p

Jacquemin SJ, Pyron M (2013) Effects of allometry, sex, and river location on morphological variation of freshwater drum Aplodinotus grunniens in the Wabash river, USA. Copeia 4: 740-749.

King M (2007) Fisheries biology, assessment and management. Second edition. Blackwell. Oxford. 349p.

Lim HK, Le MH, An CM, Kim SY, Park MS, Chang YJ (2010) Reproductive cycle of yellow croaker Larimichthys polyactis in southern waters off Korea. Fish Sciences 76: 971-980.

Luksenburg JA, Pedersen T (2002) Sexual and geographical variation in life history parameters of the shorthorn sculpin. Journal Fish Biology 61: 1453-1464.

Marcano L, Alió J, Altuve D (2002) Biometría y talla de primera madurez de la tonquicha, Cynoscion jamaicensis, de la costa norte de la península de Paria, estado Sucre, Venezuela. Zootecnia Tropical 20: 83-109.

Militelli MI, Macchi GJ, Rodrigues KA (2013) Comparative reproductive biology of Sciaenidae family species in the río de la Plata and Buenos Aires Coastal Zone, Argentina. Journal of the Marine Biological Association of the United Kingdom 93: 413-423.

Nelson JS (1994) Fishes of the World. 3th Edition Wiley and Sons. New York, NY. 600p.

Nikolsky GV (1963) The ecology of fishes. Academic, London and New York, USA. 352p.

Perera-García MA, Mendoza-Carranza M, Páramo-Delgadillo S (2008) Dinámica reproductiva y poblacional del robalo, Centropomus undecimalis (Perciforme: Centropomidae), en Barra San Pedro, Centla, México. Universidad y Ciencia 24: 49-60. 
Pombo M, Denadai MR, Santos FB, Bessa ECM, Turra A (2013) Population biology of the barbel drum Ctenosciaena gracilicirrhus (Metzelaar, 1919) (Perciformes: Sciaenidae) in Caraguatatuba Bay, Southeastern Brazil. Brazilian Journal of Oceanography 61:169-175.

Potts WM, Sauer WHH, Henriques R, Sequesseque S, Santos CV, Shaw PW (2010) The biology, life history and management needs of a large sciaenid fish, Argyrosomus coronus, in Angola. African Journal of Marine Science 32: 247-258.

Ramos-Cruz S (2009) Relación longitud-peso y factor de condición en el barrilete negro Euthynnus lineatus (Kishinouye, 1920) (Perciformes: Scombridae), capturado en el litoral de Oaxaca, México. Revista Investigación Marina 30: 45-53.

Ramos-Miranda J, Bejarano-Hau K, Flores-Hernández D, Ayala-Pérez LA (2009) Growth, mortality, maturity, and recruitment of the star drum (Stellifer lanceolatus) in the southern Gulf of Mexico. Ciencias Marinas 35: $245-257$.

Ricker WE (1958) Handbook of computations for biological statistics of fish population. Computation and interpretation of biological statistics of fish populations. Bulletin of the Fisheries Research Board of Canada 119: 1-302.

Ricker WE (1975) Computation and interpretation of biological statistics of fish populations. Bulletin of the Fisheries Research Board of Canada 191: 1-382.

Rodríguez-Gutiérrez M (1992) Técnicas de evaluación cuantitativa de la madurez gonádica en peces. AGT. México, DF. 79p.

Rypel AL (2007) Sexual dimorphism in growth of freshwater drum. Southeastern Naturalist 6: 333-342.

Rypel AL, Bayne DR, Mitchell JB (2006) Freshwater drum growth from lentic and lotic habitats in Alabama. Transactions of the American Fisheries Society 135: 987-997.

Saborido RF (2005) Ecología de la reproducción y potencial reproductivo en poblaciones de peces marinos. Instituto de Investigaciones Marinas, Universidad de Vigo, España. 155p.

Sirangelo BA, Ferreira FN (2004) Reproductive biology of Mentecirrhus littoralis in southern Brazil (Actinopterygii: Perciformes: Sciaenidae) Neotropical Ichthyology 2:31-36.

Sokal RR, RohlfFJ (1996) Biometry: The principles and practice of statistics in Biological Research. Freeman, New York, USA. 887p.

Sparre P, Venema SC (1998) Introducción a la evaluación de recursos pesqueros tropicales, Parte 1 manual. FAO, Santiago de Chile, Chile. 420p.

Swedberg DV, Walburg CH (1970) Spawning and early life history of the freshwater drum in Lewis and Clark Lake, Missouri River. Transactions of the American Fisheries Society 99: 560-570.

Underwood AJ (1997) Experiments in ecology. Their logical design and interpretation using analysis of variance. Cambridge University, Cambridge, United Kingdom 506p.

Wallus R, Simon TP (2006) Reproductive Biology and Early Life History of Fishes in the Ohio River Drainage: Aphredoderidae through Cottidae, Moronidae, and Sciaenidae, Vol. 5. 336p.

Zar JH (1999) Biostatistical analysis. 3th Edition. Prentice-Hall, New Jersey, USA. 929p. 